\title{
Before It's Too Late: Preventing Genocide by Holding the Territorial State Responsible for Not Taking Preventive Action
}

\author{
Etienne Ruvebana ${ }^{1} \cdot$ Marcel Brus ${ }^{2}$
}

Published online: 29 April 2015

(C) The Author(s) 2015. This article is published with open access at Springerlink.com

\begin{abstract}
It is widely accepted in international law that the responsibility of states for the breach of an obligation to prevent a given event occurs when that event takes place. When applied to the obligation to prevent genocide, it would mean that the breach of that obligation commences when genocide occurs. If that is the case, this would appear to be in conflict with the aim of the rules on the responsibility of states and the aim of the primary rule on the obligation to prevent genocide. This conflict has not been fully addressed in the literature. This contribution examines whether and to what extent under the existing rules of international law on the prevention of genocide it is possible to hold territorial states responsible for the breach of that obligation before genocide occurs or never occurs. It will be argued that international law does not provide a general rule which is applicable to all obligations to prevent and that the moment of the breach depends on the content and nature of each obligation and the event to be prevented. The nature and content of the obligation to prevent genocide dictates that its breach commences at the moment a state fails to do what that obligation requires it to do and not at the moment genocide is committed. The legal consequences of state responsibility for not taking measures to prevent genocide as well as the invocation of the responsibility are addressed, leading to the conclusion that an international mechanism seems to be required to effectively implement the responsibility of the territorial state to prevent genocide.
\end{abstract}

Keywords Prevention - Genocide convention - State responsibility - Territorial states - Legal consequences - International mechanism to prevent genocide

Marcel Brus

m.m.t.a.brus@rug.nl

Etienne Ruvebana

eruvebana@gmail.com

1 School of Law, University of Rwanda, Huye, Kigali, Rwanda

2 University of Groningen, Groningen, The Netherlands 


\section{Introduction}

The prohibition of genocide is one of the most fundamental norms of international law and is accepted as having the status of a peremptory or jus cogens norm in international law. Nevertheless, it is only to a limited extent that the international community seems to be able to prevent genocide from occurring as is shown by the mass atrocities that (may) qualify as genocide that have occurred in, for example, Rwanda, Bosnia, Sri Lanka, Sudan, Syria, Congo, or the Central African Republic. The 1948 Genocide Convention ${ }^{1}$ confirms in Article I that the States Parties accept the duty to prevent (and punish) genocide as a crime under international law. In Bosnia v. Serbia the International Court of Justice (ICJ) held Serbia responsible under international law for not taking the necessary measures in accordance with its due diligence obligation to prevent genocide in Bosnia. ${ }^{2}$ In this particular case the ICJ had determined that genocide had taken place. The questions that will be addressed in this article is whether the duty of prevention can be breached in a situation where genocide has not (yet) occurred, what the possible consequences of such a breach are and who can invoke such responsibility.

The present analysis will be limited to the breach of the duty of prevention by the territorial state, that is the state on whose territory the acts or omissions to act take place and that may lead to genocide. The analysis does not cover the breach of the duties to prevent by third states, like Serbia with regard to the genocide that took place in Bosnia, and the United Nations or other international organizations; that will have to be left for a future publication.

A major problem arising in respect of a duty to prevent a certain event or effect from happening is whether that duty is breached only if and when that event or effect occurs. In other words, is the duty to prevent genocide as an international legal obligation only breached if genocide takes place? There is no doubt that it is widely accepted in international law that the responsibility of states for the breach of an obligation to prevent a given event occurs when that event actually occurs. This has even been codified in Article 14(3) of the Articles on the Responsibility of States for International Wrongful Acts (ARSIWA), which states that 'the breach of an international obligation requiring a state to prevent a given event occurs when the event occurs' ${ }^{3}$ This has been reaffirmed and applied by the ICJ in Bosnia v. Serbia. ${ }^{4}$ Literally applied to the obligation to prevent genocide, this would mean that a breach of the duty to prevent commences when genocide occurs. However, this would appear to be in conflict with the purpose of the rules on state responsibility

\footnotetext{
${ }^{1}$ Convention on the Prevention and Punishment of the Crime of Genocide, adopted by Resolution 260 (III) A of the United Nations General Assembly on 9 December 1948.

${ }^{2}$ ICJ, Application of the Convention on the Prevention and Punishment of the Crime of Genocide (Bosnia-Herzegovina v. Serbia-Montenegro) (Case No. 91), Judgment (Merits) 26 February 2007, para. 431, at www.icj-cij.org.

${ }^{3}$ Art. 14 of the ILC Articles on the Responsibility of States for International Wrongful Acts (ARSIWA), with Commentary, 2001, Annex to General Assembly Resolution 56/83 of 12 December 2001, and corrected by document A/56/49(Vol. I)/Corr.4, p. 60.

${ }^{4}$ The ICJ ruled in Bosnia v. Serbia that the obligation to prevent genocide is only breached if genocide is in fact committed. Supra n. 2, para. 431.
} 
which is to hold states responsible for their wrongful acts (actions and omissions), ${ }^{5}$ and with the purpose of the primary rule on the obligation to prevent genocide which is to avoid the occurrence of genocide. ${ }^{6}$ This conflict has not been fully addressed in the literature. Instead, the position that the event has to arise as a condition for the breach of the obligation to prevent has been rather uncritically followed without giving due consideration to the nature of the obligation in question and the event to be prevented.

This contribution is based on earlier research that will be briefly discussed in Sect. 2. It concentrated on the temporal scope of the obligation to prevent genocide under international law and the corresponding measures that could or should be taken by the territorial states, third states and the United Nations in complying with their respective legal duties. ${ }^{7}$ This resulted in various recommendations, including that the bearers of the obligation to prevent genocide should be held responsible when they breach it and should face legal consequences. ${ }^{8}$ This recommendation is further elaborated upon in this article. Section 3 examines whether international law provides a general rule to determine the moment when an obligation to prevent is breached and in Sect. 4 this is applied to whether and how territorial states can be said to have breached the obligation to prevent genocide irrespective of the fact whether genocide has occurred. This forms the core of this article. Clarifying this aspect should contribute to making international law more effective as one of the instruments to prevent genocide. In Sect. 5 observations will be made on the consequences of such responsibility and the question of invocation will be addressed, and it will be shown that in particular on these aspects the regime related to state responsibility requires further development.

Designing more effective methods for holding states responsible for a breach of the duty to prevent genocide before it takes places, whether through international institutions like the UN, human rights mechanisms, or through inter-state mechanisms, starts with providing clarity about the obligation for states to prevent genocide. States have accepted the obligation to prevent genocide in Article 1 of the Genocide Convention of 1948: 'The Contracting Parties confirm that genocide, whether committed in time of peace or in time of war, is a crime under international law which they undertake to prevent and to punish'. Among others in 2005, states have reiterated this responsibility in the context of the Responsibility to Protect (R2P). It entails the prevention of such crimes, including their incitement, through appropriate and necessary means. ${ }^{9}$ This article aims to clarify this responsibility. Even if the invocation of state responsibility in practice may not be considered very

\footnotetext{
5 Art. 1 of the ARSIWA states that 'every internationally wrongful act of a State entails the international responsibility of that State'. And according to Art. 12 of the ARSIWA, 'a breach of an international obligation by a State when an act of that State is not in conformity with what is required of it by that obligation, regardless of its origin or character'.

${ }^{6}$ Ruvebana (2014), p. 111. This is the outcome of a PhD project supervised by co-author of this article. The book was awarded the Max van der Stoel Human Rights Award 2014.

7 Ruvebana (2014), pp. 1-359.

8 Ruvebana (2014), p. 324.

9 See the 2005 UN World Summit Outcome Document (WSOD) adopted by the General Assembly, UN Doc. A/60/1 of 15 September 2005, para. 138.
} 
likely in situations where genocide had not yet occurred, it is argued that the legal obligation to prevent genocide forms the legal backbone for any measures to be taken and mechanisms to be established, individually and collectively, to prevent genocide.

\section{The Scope of the Obligation to Prevent Genocide in a Temporal Structure}

The research project that provided the basis for this contribution ${ }^{10}$ concentrated on describing and analyzing the content of the duty to prevent genocide for various categories of actors within a particular temporal structure. In this brief summary of the earlier project only the duties of the territorial state will be addressed. ${ }^{11}$

A temporal structure that was found useful to give concrete meaning to the duty of prevention and to the spirit of the Genocide Convention is a distinction in three phases or levels: primary, secondary and tertiary. The primary level refers to the period even before conflict in society that may ultimately lead to genocide has arisen. The duty to prevent genocide at this level requires states to put in place general administrative, political, educational, cultural, economic, and legal measures, including the adoption of legislation that may help to prevent or counter societal tensions that may develop into concrete conflicts that may lead to genocide in one of the following phases. ${ }^{12}$

The secondary level concerns the period in which there are symptoms of societal conflict that may lead to genocide, but before the actual start of the commission of genocidal acts. ${ }^{13}$ This is the time in which the bridge from the 'normal' situation to a potential genocidal situation is being crossed. For instance, it is a period when in a given state there is the presence of a totalitarian ruler or an authoritarian form of government ${ }^{14}$ that undertakes or allows the deprivation of resources or other forms of discrimination that target a specific group. Genocidal risks become clearly visible when the dehumanization of that group forms part of the actions against it. It may be a period in which the government undertakes or allows hate propaganda against that group, and provides impunity for the perpetrators of crimes related to this. ${ }^{15}$ In that period, armed conflict may start to occur. Such conflicts, which may be ethnically, racially, or religiously-oriented, may create a favourable environment in which the

\footnotetext{
${ }^{10}$ Ruvebana (2014), pp. 1-324.

11 Ruvebana (2014), pp. 113-159.

12 Ruvebana (2014), pp. 114-124. See also Lemkin (1944), p. 92; Schabas (2009), p. 520; Fein (2000), p. 49; Fein (1984), pp. 3-32; Adler et al. (2004), p. 2027-2051; Woolf and Hulzer (2005), p. 106; Sriram and Wermester (2003), p. 16-29; Fortali (2011), pp. 190-205; Ben-Naftali (2009), pp. 33-43; Clark (2008), pp. 103-107.

13 Ruvebana (2014), pp. 124-146.

14 In the literature this is noted as 'one key characteristic of genocidal states'; e.g. Woolf and Hulzer (2005), p. 106.

15 Ruvebana (2014), pp. 69-70.
} 
distinctions between groups are stirred up deliberately. To the outside world the conflict may appear to represent an 'ordinary' conflict in a given society, but in fact the conflicts cover (the preparation of) acts of genocide. ${ }^{16}$ Symptoms and risks that may fall within the secondary level include human rights violations such as killings, disappearances, torture, rape and sexual violence, abduction, ethnic cleansing, forced population transfer or displacement, segregation, isolation or the concentration of a group, expropriation, destruction of property, destruction of subsistence food supply, denial of water or medical attention and hate speech. ${ }^{17}$

With regard to measures at this level, it was argued that these include investigating, prosecuting and punishing people who commit crimes like incitement to hatred or discrimination against a specific group of people, persecution as a crime against humanity and incitement to commit genocide. Punishing the perpetrators of these crimes before genocide occurs is one form of complying with the obligation to prevent genocide which may have a preventive effect. When territorial states have no control over the perpetrators of the said crimes committed on or outside its territory, it was shown how international law provides for means to punish them when the crime committed is an international one. It was also shown that prevention does not only require judicial measures, but may also include other measures, such as those that may address discrimination and incitement to commit genocide through the media.

The last level is the tertiary one. It concerns the period when genocide is being committed. It was argued that the obligation to prevent genocide includes the obligation for territorial states not to commit genocide itself and to stop or at least attempt to stop acts of genocide if undertaken by non-state actors. ${ }^{18}$ This is because this obligation is continuous. It neither commences nor does it cease when acts of genocide have commenced. States are obligated to put an end to those acts regardless of where they emanate from. Measures to end it include but are not limited to those involving the use of force.

To sum up, using the temporal division of primary, secondary, and tertiary levels is useful in describing and analyzing the processes and factors that may lead to genocide and what should or could be done against it at each level. Since prevention means to take measures that aim to avoid the occurrence of genocide, and territorial states have the obligation to prevent genocide by adopting measures that preclude it from happening, it seems to follow that this obligation is owed from a very early moment in order to avoid development into a situation where genocide may occur and is not limited to the moment when genocide starts to be committed. Whether this is sufficiently reflected in the international law on state responsibility will be discussed in the following sections.

\footnotetext{
16 These conflicts have been referred to in the literature as being likely to 'obscure the genocidal killing', e.g.: Fein (1984), pp. 3-31. See also Adler et al. (2004), p. 2027-2051.

17 Efforts of the United Nations system to prevent genocide and the activities of the Special Adviser to the Secretary-General on the Prevention of Genocide, Report of the Secretary-General, 18 February 2009, A/HRC/10/30, paras. 3-10.

18 Ruvebana (2014), pp. 146-156.
} 


\section{Does International Law Provide a Generally Applicable Rule to Determine the Moment at Which an Obligation to Prevent Is Breached?}

The International Law Commission (ILC) seems to give a straightforward answer to this question in Article 14(3) of the ARSIWA: 'The breach of an international obligation requiring a state to prevent a given event occurs when the event occurs... ${ }^{19}$ Contrary to many other provisions in the ARSIWA, the commentary on Article 14(3) is limited to only one paragraph which leaves important questions unanswered. In this brief comment, the ILC refers only to the Trail Smelter case, ${ }^{20}$ and notes that the breach of the obligation to prevent transboundary damage by air pollution occurred in that situation from the time the pollution was emitted (and continued to be emitted) and that this responsibility may be 'progressively aggravated by the failure to stop it' ${ }^{21}$ The commentary discusses the difference between a continuous duty to prevent and the situation in which by the occurrence of the event the duty to prevent disappears as 'the whole point of the obligation is defeated', ${ }^{22}$ but does not deal with the question whether the omission to act to prevent a given event may constitute a wrongful act and hence lead to the invocation of state responsibility before the act to be prevented occurs.

Prior to the adoption of the ARSIWA in 2001, the ILC Special Rapporteur Roberto Ago dealt extensively with the issue in Article 23 of the Draft Articles and the commentary thereto as adopted in the first reading in 1978. Article 23 reads as follows:

When the result required of a State by an international obligation is the prevention, by means of its own choice, of the occurrence of a given event, there is a breach of that obligation only if, by the conduct adopted, the State does not achieve that result.

The ILC noted that the breach of the obligation to prevent a given event from occurring 'can be asserted to exist, and the responsibility of the State to be incurred, only if the event to be prevented actually occurs and also if lack of prevention on the part of the obligated State is proved'. ${ }^{23}$ One of the examples given in the commentary is the obligation to prevent in Article 22 of the Vienna Convention on Diplomatic Relations which requires states to ensure that premises of the mission are not subject to any intrusion or damage and that there is no disturbance of the peace of the mission or any impairment of its dignity, not only by state organs but

\footnotetext{
${ }^{19}$ See Art. 14 of the ARSIWA, supra n. 3, p. 60. A number of scholars have espoused this theory and have qualified the occurrence of the event to be prevented as a sine qua non condition of the breach of the obligation to prevent. See for instance Salmon (2010), p. 390; Economides (2010), p. 374.

${ }^{20}$ Trail Smelter case (United States v. Canada), awards of 16 April 1938 and 11 March 1941, 3 RIAA 1905.

21 See the commentary on Art. 14 of the ARSIWA, supra n. 3, p. 62, para. 14.

22 Ibid., fn. 254.

23 Report of the International Law Commission on the work of its Thirtieth session, 8 May-28 July 1978, Official Records of the General Assembly, Thirty-third session, Supplement No. 10, ILC Yearbook 1978, Vol. II(2), pp. 81-87, Art. 23 and its commentary on para. 6.
} 
also by third parties, in conjunction with the obligation in Article 29 of the same convention that requires states to take all appropriate steps to prevent any attack on the person, freedom or dignity of a foreign diplomatic agent. ${ }^{24}$ In this example, the commentary went on to imply that responsibility only arises after the intrusion in the premises or any of the other events took place, and that a causal link needs to be shown with the failure of the state to prevent it. ${ }^{25}$ However, the commentary also shows that these preconditions for the invocation of a breach of the duty to prevent typically apply to obligations of result. In the 1978 commentary, the ILC started its analysis by making a distinction between obligations of conduct and obligations of result. What Article 23 was concerned with were the obligations of result and not obligations of conduct. On this distinction the ILC stated:

When States formulate the obligations they are preparing to assume, they are free to structure them as they deem preferable in the light of the particular objective pursued. They therefore sometimes subscribe to commitments which are typically obligations 'of conduct' and which, as such, require of the State not that it ensure a result, but that it perform particular acts of commission or omission. $^{26}$

James Crawford later extensively analysed this distinction made by the ILC and the comments it provoked, and decided to delete Article 23. Among others, Crawford qualified the interpretation of Article 22 of the Vienna Convention as an obligation of result as an undesirable one, arguing that that obligation is 'a continuing obligation on the host state to take all appropriate steps to protect the mission, which becomes more demanding if for any reason the mission is invaded or disturbed'. ${ }^{27} \mathrm{He}$ thus maintained that 'States should not be able to neglect that "special duty" on the basis that intrusion, damage or disturbance has not yet occurred and may never occur'. ${ }^{28}$ He referred to the ICJ ruling in the United States Diplomatic and Consular Staff in Teheran case that:

The Iranian Government failed altogether to take any 'appropriate steps' to protect the premises, staff and archives of the United States mission against attack by the militants, and to take any steps either to prevent this attack or to stop it before it reached its completion ... [I]n the opinion of the Court ... the failure of the Iranian Government to take such steps was due to more than mere negligence or lack of appropriate means ... This inaction of the Iranian Government by itself constituted clear and serious violation of Iran's obligations to the United States under the provisions of article 22, paragraph 2. ${ }^{29}$

\footnotetext{
${ }^{24}$ See Arts. 22 and 29 of the Vienna Convention on Diplomatic Relations of 1961. See also Report of the International Law Commission 1978, supra n. 23, pp. 81-87, Art. 23 and its commentary on para. 3.

25 Supra n. 23, pp. 81-87, Art. 23 and its commentary on paras. 4, 6, 12 and 16.

26 Ibid., para. 2.

27 J. Crawford, Second Report on State Responsibility, ILC Yearbook 2008 Vol. I(1), pp. 4-100, para. 86.

28 Ibid.

29 United States Diplomatic and Consular Staff in Teheran, Judgment, ICJ Reports 1980, p. 3 at p. 29, paras. 63, 67. Crawford, Second Report, supra n. 27, para. 84.
} 
Seemingly, Crawford has posited in this example that the special duty in Article 22 requires states to take measures to prevent the intrusion or damage before it occurs (or never occurs), which indeed implies that the breach would occur from the moment of the failure to take measures regardless of the result. ${ }^{30}$ Pierre Dupuy has argued that the breach occurs at 'the moment that the conduct of the state has been proved not to have been in conformity with the behaviour required by the applicable law'. ${ }^{31}$ He based his argument on the premises laid down in Article 1 of the ARSIWA and maintained that 'if it is true that every international wrongful act of a state entails the international responsibility of that state, then the mere commission of that act is sufficient to make it responsible'. ${ }^{32}$ So, the actual conduct of the state is what is taken into account, not the result thereof. ${ }^{33}$ These commentators therefore seem to argue that the moment the conduct of the states is not in conformity with what the law requires is the moment from which the breach occurs. However, no one among the mentioned commentators has said explicitly that it would be possible to hold the state responsible before the occurrence of an event that is to be prevented.

However, in the whole process leading to the adoption of what is now Article 14(3) ARSIWA, it became clear that the Special Rapporteur and the commentators agree that it is the primary rule containing the obligation to prevent that needs to be examined. Crawford noted, for instance, that 'the meaning of any particular obligation depends on the interpretation of the relevant primary rule'. ${ }^{34}$ Article 23 of the 1978 ILC Articles had been so much criticized because it did not formulate secondary rules of international law in this respect, but rather focused on the primary rules of international $\operatorname{law}^{35}$ without managing to set a general rule. Apparently, neither in Ago's proposal nor in Crawford's report is there such a general rule which is applicable to all obligations to prevent. All depends on the primary rule and the nature of the event to be prevented.

Concluding this section, it is argued that just as in the previous drafts, there is no evidence that Article 14(3) of the ARSIWA of 2001 provides a general rule covering all obligations to prevent. It certainly states that the breach of the obligation to prevent occurs when the event occurs, but this seems to follow the same line of argument as in the 1978 first reading where Article 23 referred to the obligations to prevent that allow states to do so 'by means of their own choice'. Indeed, not all obligations to prevent are the same and allow that choice. Hence, it would be impossible to treat them in the same way. The responsibility of states to prevent depends on the interpretation of the content of the primary rule. In fact, while some rules which oblige states to prevent may require them to put in place specific measures that aim at preventing the occurrence of a given event, some others may not require such specific measures and leave it to their own choice. It is

\footnotetext{
30 See also Hafner and Buffard (2010), p. 523.

31 Dupuy (1999), p. 382.

32 Dupuy (1999), p. 382.

33 Dupuy (1999), p. 382.

34 Crawford, Second Report, supra n. 27, para. 90, adding that 'this process of interpretation falls outside the scope of the draft articles'.

35 Ibid., para. 84.
} 
thus difficult to lay down a general rule that may be applicable to all obligations to prevent because the primary rule and the nature of the event in each case may differ. Whether this argument may mean that the responsibility for the breach of the particular obligation to prevent genocide is possible before genocide occurs will be discussed in the next section.

\section{Can a Territorial State Be Held Responsible for the Breach of the Obligation to Prevent Genocide Before Acts of Genocide Take Place?}

Literally referring to Article 14(3) of the ARSIWA, and with no further elaboration, the ICJ unambiguously stated in Bosnia $v$. Serbia that the obligation to prevent genocide is only breached if genocide is in fact committed. ${ }^{36}$ It did however also maintain that 'it would be absurd' if this obligation to prevent genocide were only to commence when the perpetration of genocide commences 'since the whole point of the obligation is to prevent ... the occurrence of the act' ${ }^{37}$ It added that, under the obligation to prevent genocide, states have a duty to act at the instance a state learns or should have learned of the existence of a serious risk of genocide and that states are under a duty to use available means to deter genocide from happening. This is in conformity with its earlier statement that 'the obligation [to prevent genocide] is one of conduct and not one of result' and 'responsibility is however incurred when the State manifestly failed to take all measures to prevent genocide'. ${ }^{38}$ It should be kept in mind that the ICJ in Bosnia v. Serbia did not consider the obligations of the territorial state, but obligations of a third state. The present argument concerns the duties of the territorial state and not whether such duties may or may not be equally applicable to possible third states' duties to use all means available to prevent genocide in another state before genocide has taken place.

This ruling of the ICJ has been criticised in the literature for its inconsistencies. ${ }^{39}$ For instance, Andrea Gattini noticed an uncertainty in labelling Article 14(3) of the ARSIWA as a general rule of the law of state responsibility, after the same court had already stated in its order on provisional measures of 8 April 1993 that the obligation to prevent involves 'positive obligations', i.e., the obligation to do one's best to ensure that such acts do not occur. ${ }^{40}$ Also wondering why it should not be possible to hold a state responsible which manifestly breached its obligation to prevent even if the event was averted, Gattini understood that the ICJ simply 'preferred not to leave the well-trodden path of Article 14, paragraph 3'. ${ }^{41}$ Mark

\footnotetext{
36 Supra n. 2, para. 431.

37 Ibid.

38 Ibid., para. 430.

39 The result-oriented approach of the ICJ has been criticised in other contexts as well, such as in the application of the precautionary principle in international law. See e.g. Ambrus (2012), pp. 266-267. In the present article we have limited our investigation to the context of the obligation to prevent genocide and have not engaged in a much wider discussion on the application of the duty to prevent in other fields.

40 Gattini (2007), p. 701.

41 Gattini (2007), p. 702.
} 
Gibney also criticised the position of the court and opined that if state responsibility is concerned with determining whether state behaviour is "wrong" or "unlawful", it should not matter whether genocide actually is carried out or not'. ${ }^{42}$

Contrary to the ICJ ruling in Bosnia v. Serbia, in other more or less related cases, other courts have ruled in a different way. For instance, in Oyal v. Turkey, the European Court of Human Rights (ECtHR) found Turkey responsible for the violation of Article 2 on the right to life even when the applicant had not (yet) died. ${ }^{43}$ The argument of the Court was that Turkey's failure to adopt regulations in order to fulfil its positive obligation to protect the right to life resulted in the infection of the applicant with the HIV virus by blood supplied by a hospital in Turkey which put the applicant in danger. ${ }^{44}$ In Soering ${ }^{45}$ the same court did not wait for Soering to be subjected to inhuman or degrading treatment in the United States before it ruled that his extradition to that state would be a violation of Article 3 of the European Convention on Human Rights. ${ }^{46}$ In other words, the court accepted that this violation was not conditioned by the occurrence of the inhuman treatment. The International Criminal Tribunal for the former Yugoslavia (ICTY) later added in Furundzija that the jus cogens nature of the prohibition of torture makes it 'so extensive that states are even barred by international law from expelling, returning or extraditing a person to another State where there are substantial grounds for believing that the person would be in danger of being subjected to torture' ${ }^{47}$

In Furundzija, the ICTY was unequivocal with regard to the moment of state responsibility for the failure to take other preventive measures against torture such as the failure to enact necessary legislation, or alternatively to abolish inconsistent legislation. It noted that:

Normally, the maintenance of passage of international legislation inconsistent with international rules generates State responsibility and consequently gives rise to a corresponding claim for cessation and reparation (lato sensu) only when such legislation is concretely applied. By contrast, in the case of torture, the mere fact of keeping in force or passing legislation contrary to the international prohibition of torture generates international State responsibility. The value of freedom from torture is so great that it becomes imperative to preclude any national legislative act authorizing or condoning torture or at any rate capable of bringing about this effect. ${ }^{48}$

\footnotetext{
42 Gibney (2007), pp. 768-769.

43 ECtHR, Case of Oyal v. Turkey (application no. 4864/05), Judgment, Strasbourg, 23 March 2010, paras. 55, 56 and 57, available at www.echr.coe.int.

44 Ibid., paras. 49, 53, 54, 105.

45 ECtHR, Case of Soering v. The United Kingdom (application no. 1/1989/161/217), Judgment, Strasbourg, 7 July 1989, paras. 80-111, available at www.echr.coe.int.

46 This article states that: 'No one shall be subjected to torture or to inhuman or degrading treatment or punishment.'

47 ICTY, Prosecutor v. Anto Furundzija, Judgment of the Trial Chamber, 10 December 1998, para. 144, available at www.icty.org.

48 Ibid., para. 150. Emphasis added.
} 
The ICTY added with regard to laws or other national measures that would condone or authorise torture that '[p]roceedings could be initiated by potential victims if they had locus standi before a competent international or national judicial body with a view to asking it to hold the national measure to be internationally unlawful'. ${ }^{49}$ The premises for this is that laws on the prohibition of torture are peremptory norms and that international rules prohibit not only torture but also (1) the failure to adopt the national measures necessary for implementing the prohibition and (2) the maintenance in force or the passage of laws which are contrary to the prohibition. ${ }^{50}$

This ruling confirms what has been said above that it all depends on the primary rule and the nature of the event to be prevented. Moreover, as Crawford has observed with regard to the interpretation and application of the primary rules, taking into account the context and object and purpose of the primary rule is paramount. $^{51}$

As said above, it would be illogical if a state could not be held responsible for a failure to prevent genocide if, for instance, it fails to enact legislation that gives effect to the prevention of genocide. Likewise, it would be untenable, if not absurd, if a state could not be held responsible for a breach of the obligation to prevent genocide if, instead of adopting legislation that aims at preventing genocide, it puts in place laws that may pave the way for genocide like those enacted by Germany against the Jews in the 1930s. ${ }^{52}$ It would be an equally untenable interpretation if a state could not be held responsible when, instead of adopting political and educational measures that aim at preventing genocide, it develops and disseminates in schools, for instance, teaching materials that promote the superiority of some racial, ethnic or religious groups over others labelled as inferior and either dangerous for or useless in society.

It may be argued that even where the particularity of the content of the obligation to prevent genocide would not suffice to lead to the conclusion that the breach of the obligation to prevent genocide before it occurs is possible, the premises under which the ICTY has argued can be applicable to the rules on the prohibition of genocide as well. According to Articles 53 and 64 of the 1969 Vienna Convention, a treaty which conflicts with (a new) peremptory norm of general international law is or becomes void. A treaty that promotes genocide would clearly have such a consequence and be void, thereby giving effect to the duty to prevent genocide as a jus cogens norm, irrespective of the fact whether genocide has taken place. It would be difficult to argue that domestic legislation or any other measure which is not in

\footnotetext{
49 Ibid., para. 155.

50 Ibid., paras. 148 and 155.

51 Crawford, Second Report, supra n. 27, para. 77.

52 On September 15, 1935, Germany adopted the Law for the Protection of German Blood and German Honour which not only emphasized the superiority of Germans over Jews but clearly discriminated against Jews by prohibiting marriages and extramarital intercourse between them and Germans. Available online at www.jewishvirtuallibrary.org/jsource/Holocaust/nurmlaw2.html (visited on 19 October 2014).

Another law was adopted: 'The Reich Citizenship Law' which stripped Jews of their German citizenship. Available online at www.jewishvirtuallibrary.org/jsource/Holocaust/nurmlaw3.html (visited on 19 October 2014).
} 
conformity with an obligation arising from this jus cogens norm could remain in place unchallenged under the law of state responsibility until genocide has actually occurred. It can therefore be further argued that the ICTY and the ECtHR rulings referred to above support an interpretation that a territorial state could be held responsible for the breach of the obligation to prevent genocide even when genocide has not followed or will never occur. This interpretation is in conformity with the peremptory character of the norm of the prohibition which cannot be derogated from by states through treaties, customs or any domestic laws and practices.

When the process leading to genocide has progressed into a more advanced level things become even clearer. This is for instance the case when a territorial state is committing, authorizing or condoning crimes that are susceptible of leading to genocide, including: incitement to hatred, to discrimination or to commit genocide; incitement to hatred that takes the form of persecution as an act of crimes against humanity; conspiracy to commit genocide; failure to punish the perpetrators of these crimes and to take other measures to try to stop their continuation in order to avoid them escalating into genocide. ${ }^{53}$ It has been argued in the literature that Article 14(3) of the ARSIWA and the ICJ judgement are not applicable when the crimes committed are those provided for in Article III of the Genocide Convention: incitement to commit genocide and conspiracy to commit genocide. ${ }^{54}$ However, this was suggested on the assumption that the acts are committed by organs of a state or by persons whose acts are attributable to the state. ${ }^{55}$ Yet, they may be committed by other persons whose acts are not attributable to the state concerned, but whose acts must be prevented by it.

In either case, an argument can be made that since the obligation to prevent genocide includes that states 'employ all means reasonably available to them', 56 it is owed from the moment preventive measures can be taken, and that the responsibility for its breach arises at the moment the territorial state fails to take available preventive measures. In this line of argument, a territorial state can be held responsible for a breach of the obligation to prevent genocide if it fails to prevent inciting speeches. In this line of argument, the Democratic Republic of Congo could have been held responsible for such a breach when it allowed or failed to prevent

\footnotetext{
53 These crimes which may lead to genocide constitute serious breaches of international law as authoritatively and sufficiently demonstrated in legal instruments and case law. See for instance Art. 6(c) of the Charter of the International Military Tribunal for the trial and punishment of the major war criminals of the European Axis, signed in London pursuant to the agreement on the 8th day of August 1945 by the Government of the United States of America, the Provisional Government of the French Republic, the Government of the United Kingdom of Great Britain and Northern Ireland and the Government of the Union of Soviet Socialist Republics. See also Art. 5 of the ICTY Statute, Art. 3 of the ICTR Statute and Art. 7 of the Rome Statute of the ICC. See also Art. 4, 3(e) of the Statute of the ICTY as annexed to Security Council Resolution 827 of 23 May 1993. See also Art. 2, 3(e) of the Statute of the ICTR as annexed to Security Council Resolution 955 of 8 November 1994. See also the Supreme Court of Canada, Mugesera v. Canada (Minister of Citizenship and Immigration), [2005] 2 SCR 100, 2005 SCC 40, para. 148. The role that these crimes play in the process that may lead to genocide has been shown in Ruvebana (2014), pp. 125-136.

54 Gattini (2007), p. 702.

55 Gattini (2007), p. 702.

56 Bosnia v. Serbia, supra n. 2, para. 430.
} 
speeches by the Congolese Minister Mr. Abdoulaye Yerodia Ndombasi which, as the Belgian warrant later described, were 'inciting racial hatred'. 57 Those 'virulent remarks' were made by him during 'public addresses and reported by the media' and they had the effect of inciting the population to attack Congolese Tutsi residents of Kinshasa, and they resulted in several hundred deaths, the internment of Tutsis, summary executions, arbitrary arrests and unfair trials. ${ }^{58}$ Likewise, it could have been possible to hold Rwanda responsible for the breach of the obligation to prevent genocide when it failed to stop the speeches by Rwandan officials and individuals who committed crimes related to incitement to commit genocide during the period that preceded the genocide. ${ }^{59}$ Similarly, the hate propaganda that was broadcast on national radio and television against foreigners in Côte d'Ivoire in $2004^{60}$ could have engaged the responsibility of Côte d'Ivoire if it did not actively try to stop this propaganda even where it was not followed by genocide, including by shutting down these radio or television stations.

These crimes are serious breaches of international law that can lead to genocide. Waiting for genocide to happen before the state can be held responsible for not taking available measures would defeat the purpose of one of the most fundamental primary rules in international law: the prohibition on committing genocide and the duty to prevent it.

To sum up, it is argued that given the nature and content of the obligation to prevent genocide and the values that the norms on the prohibition of genocide aim to protect, failing to take measures required for the prevention of genocide is a sufficient ground for triggering the responsibility of a territorial state even before genocide occurs. This interpretation should prevail over any contrary interpretation. However, it is one thing to say that a territorial state can be held responsible for the breach of the obligation to prevent genocide before genocide occurs; it is quite another thing to say who can invoke the responsibility and what legal consequences follow from such a breach. This is discussed in the next section.

\section{The Legal Consequences and Invocation of the Responsibility of Territorial States for the Breach of the Obligation to Prevent Genocide Before Genocide Occurs}

The wrongful act, and therefore also the consequences attached thereto under international law, arise at the moment that the duty to prevent is breached. In this section the relevant rules of the law of state responsibility related to the invocation

\footnotetext{
57 ICJ, Arrest Warrant of 11 April 200 (Democratic Republic of the Congo v. Belgium), Judgment of 14 February 2002, para. 67.

58 Ibid.

59 See for instance Mugesera case. He was accused of the crime of public and direct incitement to commit genocide (among other crimes) which he committed in November 1992 in Rwanda (several months before the actual genocide). Supreme Court of Canada, Mugesera v. Canada (Minister of Citizenship and Immigration), [2005] 2 SCR 100, 2005 SCC 40.

60 This triggered Security Council resolution 1572 of 15 November 2004, which ordered 'the government of Côte d'Ivoire to stop all radio and television broadcasting inciting hatred, intolerance and violence'.
} 
and consequences of such a breach will be discussed. It is acknowledged that these rules are imperfectly drafted for the purpose of dealing with the complex situations that arise related to the (breach of) the duty to prevent genocide. However, before these imperfections can be addressed in the concluding part of this article, it is necessary to first discuss the relevant rules in the ARSIWA.

\subsection{Legal Consequences of a Breach of the Obligation to Prevent Genocide by Territorial States Before Genocide Occurs}

ARSIWA distinguishes two categories of consequences: the ordinary legal consequences of the breach of international obligations and the particular consequences of serious breaches of international obligations. Both will be discussed in relation to how they can be applied to the breach of the obligation to prevent genocide before genocide occurs. The ordinary legal consequences of the breach of an international obligation are the obligation to cease the wrongful act, the obligation to offer assurances and guarantees of non-repetition and the obligation to make reparation for the damage caused. ${ }^{61}$

The obligation to cease the wrongful act concerns both actions and omissions contrary to what is required by the international obligation. ${ }^{62}$ The only conditions that need to be met for this obligation to be sought are that (1) the breach must occur at the time the obligation concerned is in force and that (2) it is still so at the time the obligation of cessation is sought. ${ }^{63}$ When applied to the obligation to prevent genocide before genocide occurs, the obligation to cease the wrongful act may for instance concern the obligation of a territorial state to cease the omission to enact necessary laws or other necessary measures, to abolish laws and other measures that are contrary to what is required by the obligation to prevent genocide and to cease to condone, authorise or commit crimes that may lead to genocide. Undoubtedly, since the function of the obligation to cease the wrongful act is 'to put an end to a violation of international law and to safeguard the continuing validity and effectiveness of the underlying primary rule', ${ }^{64}$ the obligation to cease these acts before genocide occurs is intended to stop the violator from continuing the violation. This may lead to the non-occurrence of genocide and thus gives effect to the relevant primary norm to prevent genocide. In other words the obligation to cease the wrongful act does not only entail the duty to stop an actual genocide, but also to cease acts or omissions that may lead to genocide.

Under Article 30(b) of the ARSIWA, a state responsible for the breach of an international obligation is under an obligation to offer assurances and guarantees of non-repetition. ${ }^{65}$ As the ILC has commented, the focus of this obligation is the prevention of future breaches. ${ }^{66}$ They are sought when there are reasons to believe

\footnotetext{
61 Arts. 30 and 31 of the ARSIWA, supra n. 3.

62 Ibid., para. 2 of the commentary on Art. 30.

63 Ibid., para. 6. See also Corten (2010), p. 547.

64 Para. 5 of the commentary on Art. 30 of the ARSIWA, supra n. 3.

65 Art. 30(b) of the ARSIWA.

66 Paras. 9 and 11 of the commentary on Art. 30, supra n. 3. See also Barbier (2010), p. 551.
} 
that the mere cessation of the breach does not suffice to ensure that it will not be repeated. ${ }^{67}$ The ILC did not expressly lay down conditions that need to be met before its invocation, but decided to add the rather vague formulation 'if circumstances so require' ${ }^{68}$ The ILC justified this addition to prevent abusive or excessive claims. ${ }^{69}$ In the literature three elements have emerged that need to be taken into consideration: the risk of repetition, the seriousness of the breach and the character of the obligation breached. $^{70}$ No indication is given, however, as to whether these elements are cumulative or alternative. ${ }^{71}$ Most likely, the occurrence of either of them would suffice to meet the 'if circumstances so require' test. ${ }^{72}$ In case of a breach of the obligation to prevent genocide before genocide occurs, offering assurances and guarantees of non-repetition would meet the object and purpose of the obligation to prevent repetition. Nevertheless, it is difficult to draw a general rule on this; the risk of repetition would have to be evaluated on a case-by-case basis.

With regard to the seriousness of the breach, it is irrelevant to treat it separately from the one on the character of the obligation breached since the obligation to prevent genocide arises under a peremptory norm of general international law. Hence, for instance, the failure of a territorial state to enact and apply necessary legislation to prevent genocide, the adoption of legislation that incites genocide, or its failure to repeal such legislation, may arguably meet the two elements and therefore may give rise to requiring the responsible state to assure and guarantee that it will not repeat this in the future. The appropriateness of such assurances must again be established on a case-by-case basis. For instance, in Bosnia v. Serbia the ICJ did not order Serbia to assure and guarantee non-repetition in response to the concerns expressed by the applicant that movements in Serbia calling for genocide may not have disappeared. The court concluded that the indications provided were not a sufficient ground for requiring guarantees of non-repetition. As far as the breach of the duty to prosecute was concerned, the ICJ concluded that its declaration on Serbia's breach and continuing duties in this respect was sufficient and did not require further assurances and guarantees of non-repetition. ${ }^{73}$ In any case, what is aimed at is the non-repetition of the breach. If that can be achieved through other legal consequences, the appropriateness of assurances and guarantees would be lost.

Under Article 31 of the ARSIWA, a state which has breached an international obligation is under the obligation to make full reparation for the injury caused. ${ }^{74}$ The injury may be material or moral and must have been caused by the wrongful act of the responsible state. In order to apply this to the breach of the obligation to prevent genocide the important question arises whether any material or moral

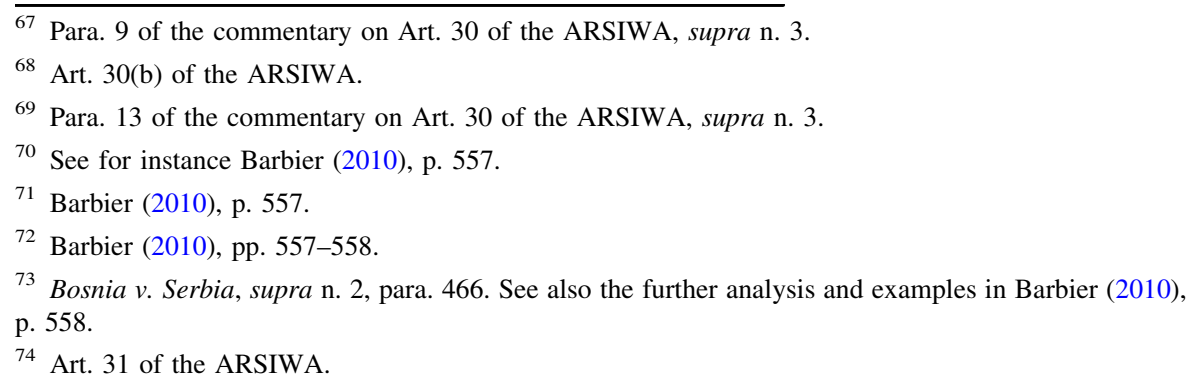


damage is inflicted before genocide occurs. The examples given above on the omission to enact necessary laws to ban genocide or the enactment of laws that may encourage, condone or authorise genocide are relevant here as well. Would it for instance be impossible to say that the Law for the Protection of German Blood and German Honour, which proclaimed the superiority of Germans over Jews and prohibited marriages between them and Germans, did cause injury to the Jews before the Holocaust ${ }^{75}$ It may not only have morally affected the Jews, but material damage was clearly suffered by, for instance, Jews who decided to flee the country. However, it may be impossible and unnecessary to determine here the exact extent of the injury because it will depend on the circumstances in each case. It suffices to say that the wrongful act of not preventing genocide may give rise to the obligation to make reparation before genocide happens. In each case the existence of the injury and the causal link between the wrongful act of the responsible state will have to be determined.

Article 41 of the ARSIWA sets out three additional (particular) consequences for all states in case of serious breaches of obligations arising under a peremptory norm of general international law. Those consequences are the obligation to cooperate to bring an end to serious breaches, the obligation not to recognize as lawful a situation created by them, and the obligation not to render aid or assistance in maintaining a situation created by them. ${ }^{76}$ For these particular consequences to apply, two criteria set out by Article 40 must be met. The first requires that the breach arises under a peremptory norm of general international law. ${ }^{77}$ The second qualifies the intensity of the breach, which must have been serious in nature. ${ }^{78}$

With regard to the first criterion, there is no longer any question that the rules regarding the prohibition of genocide are considered to be peremptory norms. As argued earlier, ${ }^{79}$ this includes the duty to prevent genocide and a breach of this obligation is clearly 'arising under a peremptory norm', also when it arises before genocide occurs or never occurs.

As for the second criterion, such a breach is considered serious if it involves a gross or systematic failure by the responsible state to fulfil the obligation. ${ }^{80}$ The word 'serious' signifies that a certain order of magnitude of the violation is necessary. ${ }^{81}$ For a violation to be systematic, it would have to be carried out in an organized and deliberate way. ${ }^{82}$ The term 'gross' refers to the intensity of the violation or its effects, denoting violations of a flagrant nature, amounting to a direct and outright assault on the values protected by the rule. ${ }^{83}$ While some acts or

\footnotetext{
75 Supra n. 52.

76 Art. 41(1, 2) of the ARSIWA.

77 Art. 40(1) of the ARSIWA.

78 Art. 40(2) of the ARSIWA.

79 See Ruvebana (2014), pp. 99-103; Brownlie (2008), pp. 510-512. See also the commentary on Art. 40 of the ARSIWA, paras. 2-6, supra n. 3.

${ }^{80}$ Art. 40(2) of the ARSIWA.

${ }^{81}$ Para. 7 of the commentary on Art. 40 of the ARSIWA, supra n. 3.

82 Ibid.

83 Ibid.
} 
omissions by territorial states which breach the obligation to prevent genocide may meet the test of seriousness and would therefore not lead to problems in applying this provision, for less serious breaches problems may arise. Before entering into a discussion on this, it should be noted that the aim should not be to expatiate on how to distinguish between less serious breaches and serious breaches, but to wonder whether such distinction is helpful or necessary given the nature of the value to be protected.

Taken literally, the ILC seems to have provided in Article 41 that particular consequences may not be applicable to breaches that do not meet the seriousness test. This position has been questioned and criticized in the literature. For instance, in providing the example of the hostage-taking of the American and consular staff in Teheran and their subsequent detention, Nina Jørgensen, reasoning a contrario, wondered whether other states could recognize such an act as lawful and could aid or assist in maintaining that situation since it was not a gross and systematic breach arising under a peremptory norm. ${ }^{84}$ Though this example given by this author is somewhat different from what is being discussed here, it nevertheless helps to understand the problem of the limitation of the particular consequences to only serious breaches.

Paola Gaeta's criticism is even more persuasive and is more related to the discussion here. She found no good reasons for the additional consequences not to apply to less serious breaches of international law that protect the fundamental interests of the international community as a whole. ${ }^{85}$ She based her argument on the premise that the ILC itself recognizes that jus cogens rules are 'substantive rules of conduct that prohibit what has come to be intolerable because of the threat it presents to the survival of states and their people and the most basic human values', ${ }^{86}$ and therefore even in a less serious breach of a jus cogens norm, states would still be obligated not to recognise it as lawful and not to aid or assist in maintaining the situation created by that breach and to cooperate in putting an end to it. ${ }^{87}$ The possible adoption of laws similar to the Law for the Protection of German Blood and German Honour, which proclaimed the superiority of Germans over Jews and prohibited marriages between them and Germans, provides an example that can explain the necessity to apply those consequences. ${ }^{88}$ Another example is a situation in which a territorial state (in which clear tensions between racial or ethnic groups exist) organises a census aiming at the listing of people belonging to a targeted group in order to transfer that group to a place where they might be killed. Would other states be free to recognise this as lawful and would they be allowed to assist? Should they not instead cooperate in ending such a conduct? Similarly, if such a territorial state starts to build concentration camps, or starts to train militia whose members belong to one (ethnic or racial) group that will likely be used to kill another (targeted) group, would other states recognise that as lawful and would they

\footnotetext{
${ }^{84}$ Jørgensen (2010), p. 692.

85 Gaeta (2010), p. 426.

${ }^{86}$ Para. 3 of the commentary on Art. 40(1) of the ARSIWA, supra n. 3. See also Gaeta (2010), p. 426.

87 Gaeta (2010), p. 426.

88 Supra n. 52.
} 
aid or assist in that training? Likewise, would other states recognise as lawful the act of a group of individuals that overthrows a government with the aim of preparing for genocide (but before serious acts are carried out) if that can be surmised from some particular circumstances?

Undoubtedly, the scenarios in all these examples are in violation of the rules prohibiting genocide which are jus cogens. They constitute a breach of the obligation to prevent genocide. Although they might not yet meet the test of serious breaches, they arguably deserve the additional particular consequences because of, as Gaeta has noted, the "extraordinary importance of the interests protected by all rules of jus cogens, ${ }^{89}$ regardless of the level of gravity of the breach.

It can thus finally be argued in line with Gaeta's argument that in addition to the ordinary consequences of the breach of the obligation to prevent genocide as an 'ordinary' wrongful act, the additional particular consequences of such a breach arising under a peremptory norm would also be applicable. The obligation to cooperate in ending the breach should be understood as involving measures that are proportionate to the seriousness of the breach. The other consequences (the obligations of non-recognition and not to render aid or assistance) are even clearer since it would be absolutely illogical to maintain that states would be allowed to recognise the situation that is created by those breaches or to render aid or assistance to the responsible territorial state which would be clearly in violation of Article 16 ARSIWA. ${ }^{90}$ Any breach arising from jus cogens norms should be considered as serious and therefore the particular consequences should be applicable. But who may invoke such responsibility against a territorial state and claim the legal consequences thereof? This will be dealt with next.

\subsection{The Invocation of the Responsibility of Territorial States for the Breach of the Obligation to Prevent Genocide}

Under Article 48(1)b of the ARSIWA, any state other than the injured state is entitled to invoke the responsibility of another state if the obligation breached is owed to the international community as a whole. ${ }^{91}$ Paragraph 2 of the same article adds that any state entitled to invoke the responsibility may claim from the responsible state either the cessation of the breach, assurances and guarantees of non-repetition, or the performance of the obligation to make reparation. ${ }^{92}$

Theoretically, since the obligation to prevent genocide is owed to the international community as a whole, it can appear easy to say that Article 48 of the ARSIWA provides an answer to the question of who may invoke the responsibility of a territorial state in case of the breach of that obligation and may claim from that state the related consequences. However, when it comes to the application of this article to the breach of the obligation to prevent genocide before

\footnotetext{
89 Gaeta (2010), p. 426.

90 Gaeta (2010), p. 426. For more on the particular consequences of the breach of international obligations see Dawidowicz (2010), pp. 679-685; Jørgensen (2010), p. 691.

91 Art. 48(1)(b) of the ARSIWA.

92 Art. 48(2) of the ARSIWA.
} 
genocide occurs, the reality shows a different picture. So far, there is no practice of states invoking the responsibility of a territorial state in situations where genocide has not (yet) occurred, not even with regard to the first two consequences (cessation and guarantees of non-repetition) which appear not to be too difficult for any state to claim. Unfortunately, this is not due to the lack of situations that could trigger such invocation, but quite likely, and in as far as legal aspects are concerned, due to the lack of clarity as to whether claims related to the breach of the duty to prevent would be admissible in international law. Moreover, states may be reluctant to engage in such claims because there is no certainty that the breach of prevention before genocide has occurred may be serious enough to trigger them.

Another reason for this reluctance is the absence of direct injury to third states. Of course theoretically (legally) all members of the international community can be said to be injured by breaches of a peremptory norm, but in reality this is not the same as when the state is directly affected. Indeed, so far states have not shown much interest in holding territorial states responsible for breaching the obligation to prevent genocide before genocide occurs, or for that matter any other obligation arising under a peremptory norm. Of course, the lack of any direct injury to third states is an issue of a more general nature and is not limited to the prevention of genocide, but as in other areas of international law, that should lead to establishing effective mechanisms to hold states to account for such violations of (fundamental) international norms.

With regard to claiming reparation, difficulties also arise. Any state could theoretically make a claim for reparation in the interest of the injured state or of other beneficiaries of the obligation breached. ${ }^{93}$ In the case where a territorial state has failed to adopt measures that prevent genocide or has adopted those that may lead to genocide, it is clearly not an injured state for the interest of which the reparation could be claimed. The beneficiaries of the reparation would be the affected parts of the population of that state. Also in this regard there is no practice to assess the feasibility of such claims. Realistically, it does not seem very likely that in the current state of affairs, states would engage in claiming reparation on behalf of (parts of) a population when the obligation to prevent genocide is breached before genocide takes place.

For the other consequences, notably cessation and assurances of non-repetition, the invocation may take place in a more indirect manner. This is presumably partly due to the fact that, in particular regarding cessation, the desired effect can be achieved without making an explicit claim under Article 48. For instance, regarding UN accusations that Rwanda had coordinated the creation of the Congolese rebel movement M23 and its major military operations, ${ }^{94}$ and the accusations that M23 engaged in grave ethnic-based violations of human rights which included arbitrary executions, enforced disappearances, degrading treatment and rape in Goma and the surroundings, ${ }^{95}$ some states suspended their aid and assistance to Rwanda because

\footnotetext{
93 Art. 48(1) and (2) of the ARSIWA.

94 See Report of the Group of Experts on the Democratic Republic of Congo addressed to the Security Council Committee, 12 November 2012, pp. 6-13, UN Doc. S/2012/843.

95 See Security Council Monthly Forecast, February 2013, available at www.securitycouncilreport.org/ monthly-forecast/2013-02/democratic_republic_of_the_congo_1.php (visited on 11 January 2015).
} 
such aid was allegedly being used to support M23. ${ }^{96}$ This also corresponds to what the obligation not to render aid or assistance to the (territorial) state requires.

Another possible obstacle to the invocation of responsibility under Article 48 is the rather categorical manner in which the ICJ noted in Bosnia v. Serbia that the responsibility for the obligation to prevent genocide can only be breached if genocide is committed. Though as discussed above this can be and has been challenged, it would be difficult and courageous for states to bring a case before that very court to invoke such responsibility before genocide is committed. The alternative of having national courts addressing this issue is not promising. This alternative has been tried before (many years after the crimes were committed) and it has been unsuccessful because of other challenges, including state immunity. ${ }^{97}$

Yet another challenge is the lack of coordination. The fact that it is left to states individually to invoke responsibility under Article 48 makes it a rather unattractive provision. Few states will be prepared to take the effort to make such claims without having a direct interest. In order to make the mechanism of Article 48 meaningful, it can be argued that not only international law needs to be developed further to clarify the many issues discussed in this article, but also that an international mechanism for coordination and implementation is necessary. Although in the current international climate it is not very likely that such a mechanism could be established any time soon, the present analysis shows that this may still be more realistic than waiting for individual states to invoke state responsibility of the territorial state for not doing enough to prevent genocide before genocide takes place and to claim reparation or other forms of redress for victims. Claims for violations of duties owed to the international community should be made collectively on behalf of that community. Arguably, the creation of an Organisation for the Prevention of Genocide (OPG), as suggested by Ruvebana, ${ }^{98}$ or any other mechanism to provide a more collective response, should be seriously considered. This Organisation or mechanism should be given the mandate to hold states responsible for breaching the duty to prevent genocide and to claim the consequences of the breach on behalf of the people affected.

\section{Conclusion}

One of the main conclusions is that neither Article 14(3) ARSIWA nor any other secondary rule provides one general rule, applicable to all obligations to prevent, with regard to the moment the breach of the obligation to prevent is said to have occurred. The nature and content of the primary rule determine the moment from which the breach occurs.

\footnotetext{
96 Those states include the Netherlands, Sweden, Germany, the United Kingdom and the United States. See for details the European Union Parliament Resolution of 13 December 2012 on the Democratic Republic of Congo, para. I, available at www.europarl.europa.eu/document/activities/cont/201301/ 20130109ATT58700/20130109ATT58700EN.pdf (visited on 11 January 2015).

97 ICJ, Jurisdictional Immunities of the State (Germany v. Italy: Greece intervening), Judgement, 3 February 2012, paras. 81-104.

98 Ruvebana (2014), p. 225.
} 
With regard to the specific obligation to prevent genocide, it is concluded that its nature and content dictate that the responsibility of territorial states for its breach arises at the moment the behaviour of that state is in violation of that norm and not only if this violation has led to the occurrence of genocide. Indeed, since the obligation to prevent genocide by territorial states entails the taking of concrete action not only to ensure the non-occurrence of genocide, but also to actively counter behaviour that may lead to it, there seems to be no justification to limit the responsibility to the moment genocide has occurred. If the responsibility for the breach of the obligation to prevent genocide would only arise after genocide happens, not only the obligation to prevent genocide would have little legal significance, but also its character as a peremptory norm would be seriously impeded. If a contrary interpretation were to prevail, it would render the obligation to prevent genocide unenforceable and it would be inconsistent with the jus cogens status of the prohibition of genocide. The duty to prevent cannot be seen as being legally separate from the prohibition of genocide as a fundamental norm of the international community. The 2001 ILC's ARSIWA have paved the way for further development in regard of obligations erga omnes and peremptory norms, but many questions remain and the ILC should give this further thought in order to ensure its applicability in complex situations such as the duty to prevent genocide.

With regard to the application of the legal consequences to the breach of the obligation to prevent genocide and its invocation, it has been concluded that the ordinary legal consequences would be applicable to the breach of the obligation to prevent genocide before genocide occurs. In addition, the particular legal consequences of Article 48 ARSIWA apply regardless of the level of gravity of the breach, because of the "extraordinary importance of the interests protected by all rules of jus cogens'. 99 For both categories of legal consequences, each state is entitled to invoke them. This follows from the conclusion that territorial states should be held responsible for the breach of that obligation from the moment that the territorial state fails to take the required actions to prevent genocide.

Finally, the availability of rules that allow territorial states to be held responsible for the breach of the obligation to prevent genocide before genocide occurs could have a positive effect on the prevention of genocide. However, serious challenges may hinder the invocation of the responsibility of the territorial state by individual states. Adequate international and national mechanisms to monitor the implementation of the obligation to prevent genocide by territorial states seem to be required to fill the responsibility gap. The development of such mechanisms could contribute to the clarification of some general issues in international law as discussed in this contribution, but also to concrete measures that can be taken in specific situations where territorial states engage in breaching the obligation to prevent genocide before genocide occurs. Channelling (state) responsibility for the breach of the obligation to prevent genocide through an international mechanism does not necessarily have to take the form of negative consequences for the state involved, but could also take the form of providing positive suggestions and assistance to counter trends that may lead to genocide. This would probably be more feasible and

99 Gaeta (2010), p. 426. 
more effective than requiring individual states to hold territorial states responsible. Amending the Genocide Convention or adopting an additional protocol to create international and national monitoring mechanisms with a mandate to address the failure of states to take relevant measures to prevent genocide would be a clear advancement of international law and should have a great impact on the prevention of genocide at all levels, be it at an early stage by suggesting relevant legislation or in the final stages in which genocide is likely to be committed or where genocidal acts have started and must be halted.

Acknowledgments The authors thank Ksenija Korolova, student at the University of Groningen, for her assistance.

Open Access This article is distributed under the terms of the Creative Commons Attribution 4.0 International License (http://creativecommons.org/licenses/by/4.0/), which permits unrestricted use, distribution, and reproduction in any medium, provided you give appropriate credit to the original author(s) and the source, provide a link to the Creative Commons license, and indicate if changes were made.

\section{References}

Adler R et al (2004) To prevent, react and rebuild, health research and the prevention of genocide. Health Serv Res 39:2027-2051

Ambrus M (2012) The precautionary principle and a fair burden of proof in international environmental law. Rev Eur Commun Int Environ Law 29:259-270

Barbier S (2010) Assurances and guarantees of non-repetition. In: Crawford J et al (eds) The law of international responsibility. Oxford University Press, Oxford, pp 551-563

Ben-Naftali O (2009) The obligation to prevent and to punish genocide. In: Gaeta P (ed) The UN Genocide Convention-a commentary. Oxford University Press, Oxford, pp 33-43

Brownlie I (2008) Principles of public international law, 7th edn. Oxford University Press, Oxford and New York

Clark RS (2008) State obligations under the Genocide Convention in light of the ICJ's decision in the Case Concerning the Application of the Convention on the Prevention and Punishment of the Crime of Genocide. Rutgers Law Rev 61:103-107

Corten O (2010) The obligation of cessation. In: Crawford $\mathbf{J}$ et al (eds) The law of international responsibility. Oxford University Press, Oxford, pp 547-548

Dawidowicz M (2010) The obligation of non-recognition of an unlawful situation. In: Crawford J et al (eds) The law of international responsibility. Oxford University Press, Oxford, pp 677-687

Dupuy PM (1999) Reviewing the difficulties of codification: on Ago's classification of obligations of means and the obligation of result in relation to state responsibility. Eur J Int Law 10:371-385

Economides CP (2010) Content of the obligation: obligations of means and obligations of result. In: Crawford J et al (eds) The law of international responsibility. Oxford University Press, Oxford, pp 371-383

Fein H (1984) Models of genocide and critical responses. In: Charny I (ed) Toward the understanding and prevention of genocide: proceedings of the international conference on the holocaust and genocide. Westview Press, Boulder and London, pp 3-31

Fein H (2000) Civil wars and genocide: paths and circles. Human Rights Review 1:49-61

Fortali S (2011) The legal obligation to prevent genocide-Bosnia v. Serbia and beyond. Polish Yearbook Int Law 31:190-205

Gaeta P (2010) The character of the breach. In: Crawford $\mathbf{J}$ et al (eds) The law of international responsibility. Oxford University Press, Oxford, pp 421-426

Gattini A (2007) Breach of the obligation to prevent and reparation thereof in the ICJ's genocide judgment. Eur J Int Law 18:695-713

Gibney M (2007) Genocide and state responsibility. Human Rights Law Rev 7:760-773 
Hafner G, Buffard I (2010) Obligations of prevention and the precautionary principle. In: Crawford J et al (eds) The law of international responsibility. Oxford University Press, Oxford, pp 521-537

Jørgensen NHB (2010) The obligation of non-assistance to the responsible state. In: Crawford J et al (eds) The law of international responsibility. Oxford University Press, Oxford, pp 687-693

Lemkin R (1944) Axis rule in occupied Europe: laws of occupation: analysis of government: proposals for redress. Carnergie endowment for international peace, Washington

Ruvebana E (2014) Prevention of genocide under international law, an analysis of the obligations of states and the United Nations to prevent genocide at the primary, secondary and tertiary levels. Intersentia, Cambridge

Salmon J (2010) Duration of the breach. In: Crawford J et al (eds) The law of international responsibility. Oxford University Press, Oxford, pp 383-397

Schabas WA (2009) Genocide in international law, the crime of crimes, 2nd edn. Cambridge University Press, Cambridge

Sriram C, Wermester K (2003) From promise to practice, strengthening UN capacities for the prevention of violent conflict. Lynne Rienner Publishers, Boulder and London

Woolf LM, Hulzer MR (2005) Psychosocial roots of genocide: risk, prevention and intervention. J Genoc Res 7:101-128 